\title{
Charophytes of Garda lake (Northern Italy): a preliminary assessment of diversity and distribution
}

\author{
Rossano BOLPAGNI, ${ }^{*}$ Eugenia BETTONI, ${ }^{2}$ Francesco BONOMI, ${ }^{2}$ Mariano BRESCIANI, ${ }^{3}$ Ketty CARAFFINI, ${ }^{2}$ \\ Silvia COSTARAOSS, ${ }^{4}$ Federica GIACOMAZZI, ${ }^{5}$ Catia MONAUNI, ${ }^{4}$ Paola MONTANARI, ${ }^{2}$ Maria Cristina MOSCONI, ${ }^{5}$ \\ Alessandro OGGIONI, ${ }^{6}$ Giovanna PELLEGRINI, ${ }^{7}$ Chiara ZAMPIERI ${ }^{5}$
}

\begin{abstract}
${ }^{1}$ Departimento di Bioscienze, Università di Parma, v.le Usberti 11/A, 43124 Parma; ${ }^{2}$ Agenzia Regionale per la Protezione dell'Ambiente (ARPA) - Lombardia, Dipartimento di Brescia, via Cantore 20, 25100 Brescia; ${ }^{3}$ Optical Remote Sensing Group, CNRIREA, via Bassini 15, 20133 Milano; ${ }^{4}$ Agenzia Provinciale per la Protezione dell'Ambiente (APPA) - Trento, Settore Informazione e Monitoraggi, Laboratorio di Idrobiologia, via Lidorno 1, 38123 Trento; ${ }^{5}$ Agenzia Regionale per la Prevenzione e Protezione Ambientale Veneto (ARPAV) - Veneto, Dipartimento di Verona, via Dominutti 8, 37135 Verona; ${ }^{6}$ Geographic Information Systems Group, CNR-IREA, via Bassini 15, 20133 Milano; ${ }^{7}$ Agenzia Provinciale per la Protezione dell'Ambiente (APPA) - Trento, Sede di Forte S. Nicolò, v.le Rovereto 146, 38066 Riva del Garda, Italy

*Corresponding author: rossano.bolpagni@unipr.it
\end{abstract}

\begin{abstract}
Charophytes (stoneworts and bassweeds) are a typical macrophytic component of inland water ecosystems. Well-developed submerged meadows of charophytes are expression of clear water and rather low phytoplankton concentrations. Consequently, among aquatic macroscopic primary producers, charophytes are one of the most threatened groups being very sensitive to phosphorous availability, turbidity and water level perturbations. Accordingly, charophytes have been suffering a massive diversity loss worldwide over the last century, mainly because of human-induced pressures. During summer 2011, detailed field surveys were carried out with the main purpose of filling knowledge gaps concerning aquatic flora and vegetation of the Garda lake - the largest lake in Italy and one of the deepest in Europe. Along randomly selected transects, floristic data were collected following standard procedures, as imposed by the Water Framework Directive. Overall, 12 different species of charophytes were recorded, which accounts for $36 \%$ of total Italian charophytes and 19\% of European species. The most diffuse species were Chara globularis and C. intermedia; whereas, the most interesting taxa were Chara polyacantha and Nitella hyalina, two species with narrow distribution in Italy. Overall in the Garda lake, dense stands of charophytes covered almost homogeneously the littoral sectors at a water depth between 3 and $12 \mathrm{~m}$. The deepest species was C. globularis, which reached a maximum depth of colonisation of about $17.5 \mathrm{~m}$. Charophytes represent a major element among the primary producers in the Garda lake. The high local charophyte diversity and the rather wide most colonised areas ( 1000-1200 ha) confirm that the Garda lake is an important reserve for many rare and threatened charophytes. For the first time, these results highlight the key role of the Garda lake for charophyte diversity at a national and European level.
\end{abstract}

Key words: macroalgae, stoneworts, subalpine deep lakes, diversity hotspot, conservation value.

Received: October 2012. Accepted: March 2013.

\section{INTRODUCTION}

Submerged macrophytes actively contribute to the promotion and maintenance of food webs and services in aquatic freshwater ecosystems (Scheffer and Jeppesen, 2007). In particular, submerged macrophytes efficiently control nutrient availability and functionality of euphotic zones providing habitat for bacteria, invertebrates and other aquatic animals (Petr, 2000; Kufel and Kufel, 2002). The Water Framework Directive (WFD) (2000/60/EC; European Commission, 2000) has recently emphasised the pivotal role of submerged macrophytes in aquatic ecosystems. The trophic status of water bodies, in fact, may be expressed in terms of macrophyte representativeness and density. It is crucial, then, to arrange complete information about macrophytes in order to correctly ad- dress recovery and management programmes of aquatic freshwater ecosystems.

In lakes, charophytes represent one of the dominant components of macroscopic primary producer communities. Charophytes are typical rapid colonisers and they constitute the majority of the total amount of plant biomass, especially below 3-4 m of depth. In general, charophytes are the deepest macrophytic colonists and their meadows are consequently the deepest submerged vegetations in lakes (Welch and Kalff, 1974; Nygaard and Sand-Jesen, 1981). Charophytes need quite good water quality and low turbidity and they decline with a progressive worsening of water (Blindow, 1992; Torn et al., 2004; Auderset Joye et al., 2002). In Europe, several charophytes have experienced a steep decline during the last century (Simons and Nat, 1996; Auderset Joye et al., 
2002). Rapid changes in charophyte dominance in favour of more competitive phanerogams, filamentous algae or phytoplankton, have been widely observed (Scheffer and Jeppesen, 2007; Azzella et al., 2013). The main causes of these changes are due to human perturbations as well as eutrophication, water abstraction, sediment mining or shoreline reinforcement (Scheffer et al., 1993; Smart et al., 2002; Azzella et al., 2013; Bolpagni, 2013). Accordingly, many charophytes are included both in red lists of threatened species and in habitats of conservative interest sensu Habitat Directive (92/43/EEC; European Commission, 1992) (Blaženčić et al., 2006; Siemińska et al., 2006; Azzella et al., 2013). In addition, the loss of the deepest macrophyte belts entails a steep simplification in habitat complexity with a progressive migration of primary producers towards the upper layers of the water column with dramatic effects on nutrients availability and gas concentrations in sediments and waters (e.g. hypoxia or anoxia) (Caraco and Cole, 2002; Bolpagni et al., 2007; Pierobon et al., 2010; Soana et al., 2011).

The enactment of the 2000 WFD resulted in a huge increase of interest in submerged macrophytes. However, up to now only few data or exclusively fragmentary information on submerged macrophytes and their ecological drivers in lakes are available. Frequently, existing records are limited to shallow waters, thus excluding completely the macrophyte contingent below 2-4 m of depth. For example, historical floristic records of the Garda lake are very scarce in spite of their essential role in developing and sustaining local and national economy. A preliminary multitemporal assessment of the macrophytic contingent of the Garda lake was performed by Bresciani et al. (2012), verifying that only three charophytes were reported for this lake in the past. Furthermore, of these three species, only Chara globularis was determined at species level (Wiegleb, 1983; Borsani et al., 2000; Bresciani et al., 2012), while the other two taxa were generally referred to as Chara and Nitella genera (Bianchini et al., 1974; Borsani and Contorbia, 2000; Ludovisi et al., 2004; Bresciani et al., 2012).

With this in mind, a systematic floristic survey was carried out during the 2011 growing season in order to meet the requests imposed by WFD and to fill knowledge gaps about the macrophytic contingent of the Garda lake. The present paper focuses on the charophytic contingent, which is considered to be the most neglected in the lake.

\section{METHODS}

\section{Study site}

The Garda lake is the largest inland lentic water ecosystem in Italy, with a surface of $368 \mathrm{~km}^{2}$, a maximum depth of about $360 \mathrm{~m}$, and a total volume of $49 \mathrm{~km}^{3}$ (Fig. 1). Garda catchment is mainly composed by sedimentary rocks
$(60 \%)$, including a minor contribution of crystalline rocks and secondarily deposited sediments (e.g. glacial and fluvial; Sauro, 2001). From an ecological point of view, the basin can be categorised as a warm, monomictic and oligomictic basin. Water column mixing takes place once in late winter or in early spring involving exclusively the uppermost portion of the water column down to a depth of about 150-200 $\mathrm{m}$. The complete circulation occurred exclusively in presence of remarkably cold winter times (Salmaso et al., 2009). As clarified by Salmaso and Mosello (2010), the Garda lake exhibits a stable oligo- to mesotrophic condition. Water transparency measured in situ with a Secchi disk (since the mid 90s of the last century) showed a summer mean value of $8.0 \pm 1.1 \mathrm{~m}$. In the light of this evidence, the potential maximum depth of macrophyte colonisation during the last three decades can be established at 14-18 $\mathrm{m}$ of depth.

Bathymetric values (e.g. mean depths and slopes), and

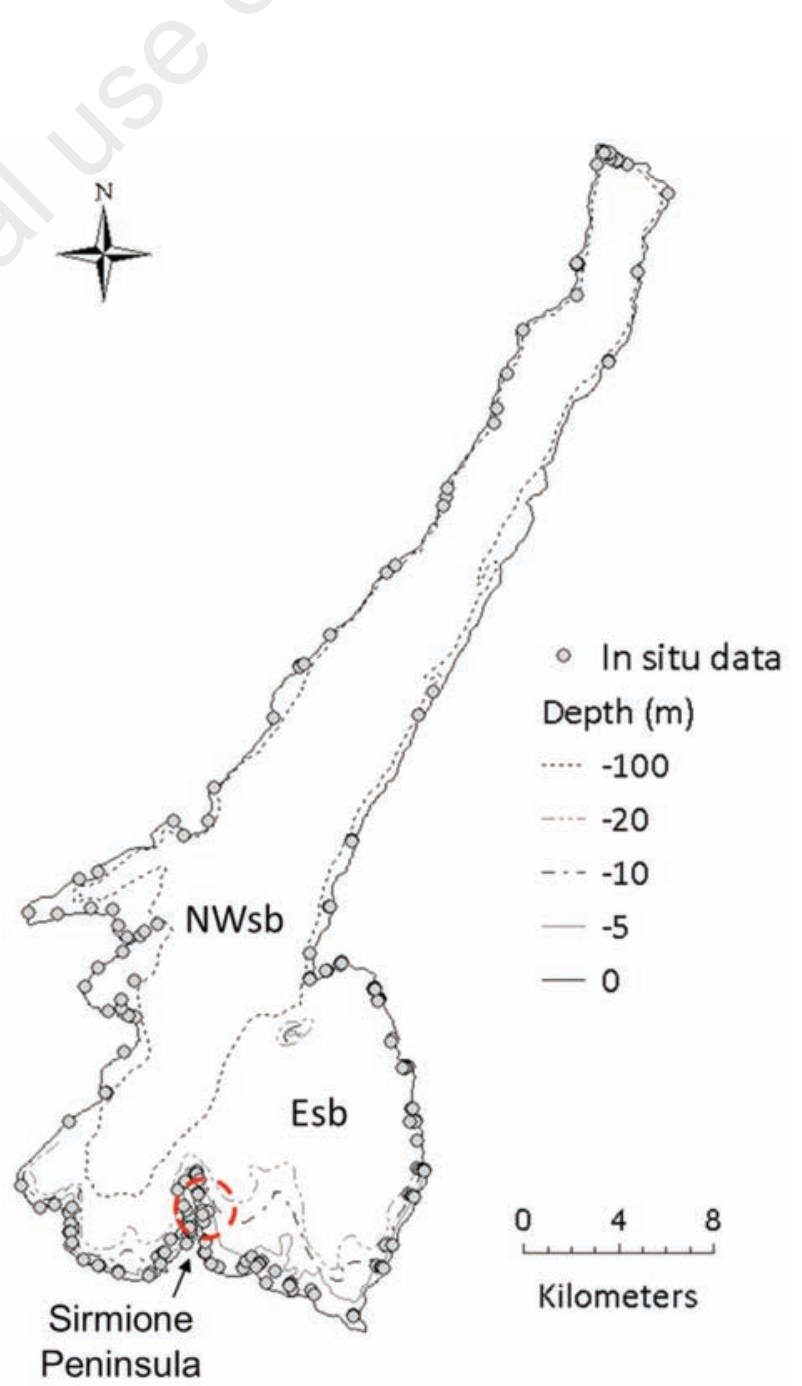

Fig. 1. Map of the study area. Accessory sampling sites are indicated by the dotted circle. 
water circulation patterns allowed to divide the lake into two main sub-basins: a north-western sub-basin (NWsb) and an eastern one (Esb). The former includes the narrow northern lacustrine sector (mean width of about $4 \mathrm{~km}$ ), that is delimited by Mt. Baldo chain (Venetian Pre-Alps) on the east, the Garda Pre-Alps (from Tremalzo-CaploneTombea group to Mt. Pizzoccolo) on the west, and the western sector corresponding to almost the entire Lombardia region portion of the lake (between Gargnano and Sirmione peninsula). On the contrary, the latter (Esb) includes the majority of the Veneto region portion of the lacustrine basin. The two sub-basins are separated by an underwater ridge connecting Sirmione peninsula to Punta S. Vigilio (Fig. 1). The north-western sub-basin is the deepest one with maximum depths up to $360 \mathrm{~m}$, a prevalence of steep slopes (especially in the northern sector), and a more rapid circulation of waters. On the contrary, Esb exhibits a more stagnant behaviour, with a maximum depth of $81 \mathrm{~m}$, mean depths not exceeding $40 \mathrm{~m}$, and very gentle slopes to the lake edge.

\section{Charophytes sampling}

Floristic data were collected during the 2011 growing seasons (July to September) following the national macrophyte survey method (Oggioni et al., 2011) developed to analyse vegetated belts in lakes according to the WFD requirements (2000/60/EC; European Commission, 2000). In brief, a representative number of transects was identified on the basis of vegetation structure and complexity of the lake littoral zone focusing on sectors which displayed maximum level of heterogeneity. Subsequently, data on macrophyte diversity and aquatic plant species abundance (\%) were collected from each 1-m depth interval up to the maximum colonisation depth. Accessory sur- veys were conducted in the southern portion of the lake on 12-14 August 2011 (Fig. 1). Charophytes nomenclature follows Bazzichelli and Abdelahad (2009).

\section{RESULTS}

On the whole, 123 transects were performed across 99 different locations (sampling areas) accounting for a total number of 865 sampling points. Overall, 12 taxa of charophytes were recorded belonging to four genera (Chara, Nitella, Nitellopsis and Tolypella) (Tab. 1). Genus Chara was the most represented with seven species (Chara contraria, C. delicatula, C. globularis, C. intermedia, C. polyacantha, C. tomentosa, C. vulgaris) followed by Nitella with three species (Nitella flexilis, $N$. gracilis, $N$. hyalina) (Tab. 1). On the other hand, both genus Nitellopsis and Tolypella were represented by only one species each (Nitellopsis obusa and Tolypella glomerata, respectively). With respect to companion species, the most common phanerogams were Vallisneria spiralis, Myriophyllum spicatum, Lagarosiphon major and Elodea nuttallii. These species appeared to be well-represented and frequent in the first meters of depth, often forming dense mats. In deeper waters, phanerogams occurred less regularly, disappearing down to 6 or $7 \mathrm{~m}$ of depth.

For the most part, charophytes were rare or uncommon, as only $C$. globularis was identified in more than $16 \%$ of the sampling transects with elevated percentage of representativeness $(76.4 \%)$. Conversely, C. polyacantha was the rarest species as it was found only in one sampling point. In the Garda lake, the maximum depth of macrophyte growth was reached by $C$. globularis and it was equal to $17.5 \mathrm{~m}$ (Tab. 1). However, N. obtusa was the species displaying the deepest range of distribution (8.8 $\pm 3.1 \mathrm{~m}$ of depth) (Fig. 2).

Tab. 1. Charophyte diversity of Garda lake.

\begin{tabular}{|c|c|c|c|}
\hline Species & N.tr. $(\%)$ & N.pl. & Zc_s \\
\hline Chara contraria A. Braun ex Kützing 1845 & $6(4.7)$ & 8 & 7.5 \\
\hline Chara delicatula C. Agardh 1824 & $2(1.6)$ & 3 & 6.5 \\
\hline Chara globularis Thuillier 1799 & $97(76.4)$ & 624 & 17.5 \\
\hline Chara intermedia A. Braun 1836 & $20(15.7)$ & 61 & 9.5 \\
\hline Chara polyacantha A. Braun in Braun, Rabenhorst \& Stizenberg 1859 & $1(0.8)$ & 1 & 3.5 \\
\hline Chara tomentosa Linnaeus 1753 & $15(11.8)$ & 39 & 8.5 \\
\hline Chara vulgaris Linnaeus 1753 & $12(9.4)$ & 68 & 12.5 \\
\hline Nitella flexilis (Linnaeus) C. Agardh $1824^{\circ}$ & - & - & 2.0 \\
\hline Nitella gracilis (Smith) C. Agardh $1824^{\circ}$ & - & - & 2.5 \\
\hline Nitella hyalina (de Candolle) C. Agardh 1824 & $13(10.2)$ & 15 & 10.5 \\
\hline Nitellopsis obtusa (Desvaux in Loiseleur-Deslongchamps) J. Groves 1919 & $16(12.6)$ & 46 & 14.5 \\
\hline Tolypella glomerata (Desvaux in Loiseleur-Deslongchamps) Leonhardi 1863 & $5(4.7)$ & 6 & 7.5 \\
\hline
\end{tabular}

N.tr., total number of transects; N.sp., sampling points where the species were identified; $Z c$ s, relative percentage of representativeness and maximum growth depth. ${ }^{\circ}$ Species recorded exclusively during the accessory floristic survey carried out in the southern portion of the lake (littoral areas are between Sirmione peninsula and lake outlet is close to Peschiera del Garda). 
In fact, analysing the distribution of the species along the depth gradient it was possible to split the underwater charophyte meadow into two distinct layers: i) an upper layer placed at medium water depths (2-6 m) mainly composed of Chara species of rather large dimensions (C. intermedia, C. tomentosa, N. hyalina, C. contraria,); and ii) a lower layer (between 6 and $12 \mathrm{~m}$ of depth), essentially composed of C. globularis and N. obtusa (Fig. 2).

A clear spatial distribution of charophytes was also revealed. The highest diversity occurred mainly in the southern sectors of the lake and in particular within the Esb. Overall, along the littoral areas delimited by Peschiera del Garda and Torri del Benaco we recorded up to 9 species (equal to the $75 \%$ of local stonewort diversity). Conversely, in NWsb only 5 species were identified (C. contraria, C. delicatula, C. globularis, C. intermedia, and C. vulgaris).

\section{DISCUSSION}

The present study has proved the presence of a vigorous and widespread contingent of charophytes along Garda lake littorals. This contingent was predominantly composed of C. globularis, C. intermedia, C. tomentosa, C. vulgaris, and $N$. obtusa species, which are typical of lentic or low-flow aquatic ecosystems (Bazzichelli and Abdelahad, 2009).
These taxa are an important component of macrophyte communities in stable habitats exhibiting medium to large size, such as lakes, reservoirs, etc.

In the Garda lake, charophytes have shown low to moderate level of diffusion (ranging from 12 to 20 transects) with the exception of $C$. globularis which was detected within 97 different transects. On a local scale, the analysis of the vertical distribution of charophytes indicated a characteristic structural sharing that is similar to those experimentally observed in analogous calcareous deep lakes (Pall and Moser, 2009). With respect to the expected communities dominated by Chara sp. in deep lakes, namely the charophytic meadows of i) shallow (Cha_sw), ii) medium (Cha_md) and iii) deep water (Cha_dw) (Middelboe and Markager, 1997; Schwarz et al., 2002; Pall and Moser, 2009), we recognised the presence of charophytic belts exclusively at medium (between 2 and 6 m of depth) and rather deep waters (below $6 \mathrm{~m}$ of depth). In particular, similarly to what observed by Pall and Moser (2009) in the lakes of northern limestone foothills and central crystalline Alps, C. globularis and $N$. obtusa represent the deepest charophytes of the primary producer contingent of the Garda lake. On the other hand, no evidences of the existence of specific mats of charophytes along the lake shorelines were collected (between 0 and $2 \mathrm{~m}$ of depth), with the exception

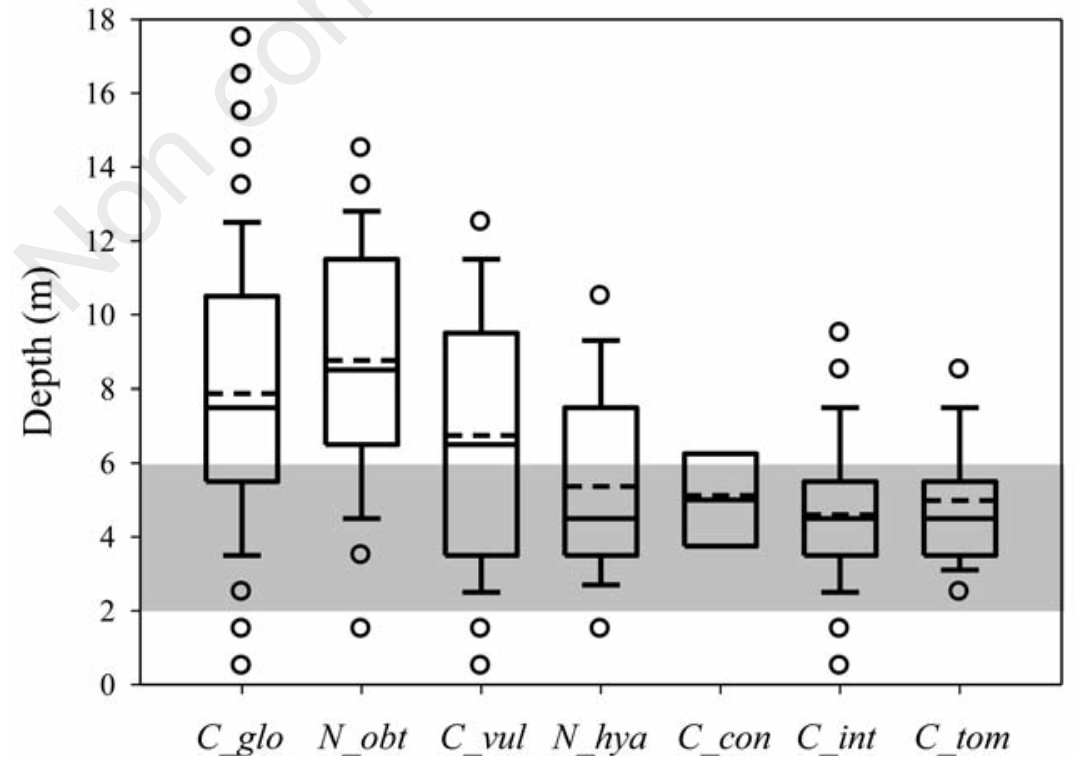

Fig. 2. The box plot graph illustrates the depth-distribution of the most represented species (with total frequencies more than $2 \%$ ). The central rectangle spans the first quartile to the third quartile; unbroken lines illustrate the median, while dashed lines show the mean. Whiskers illustrate the inner fences delimiting the adjacent values, and circles show outliers. $C \_$glo=Chara globularis, $N \_$obt=Nitellopsis obtusa, $C \_v u l=C h a r a$ vulgaris, $N \_$hya $=$Nitella hyalina, $C \_c o n=C h a r a$ con traria, $C_{\text {_int }}=$ Chara intermedia, $C_{\text {_tom }}=$ Chara tomentosa. 
of sporadic records of C. vulgaris between 1 and $2 \mathrm{~m}$ of depth.

During the past 20 years, the Garda lake exhibited a dramatic decrease in aquatic vegetation: along its shorelines, especially in the southern portions, the submerged plant meadows were actively replaced by bare or sparsely vegetated sediments. As clarified by Bresciani et al. (2012), the rapid reduction of water transparency and the increase of water level fluctuation magnitude were the two major causes leading the loss of macrophyte beds. In light of these suggestions, we argue that the complete absence of charophyte stands between 0 and $2 \mathrm{~m}$ of depth (Ch sw sensu Pall and Moser, 2009) and the loss of well-structured charophyte vegetation between 2 and $6 \mathrm{~m}$ (Ch_md sensu Pall and Moser, 2009) are the result of intense use of the shallow and littoral areas of the lake by humans, water pollution and artificial perturbations of the water level. Below $6 \mathrm{~m}$ of depth, dense meadows dominated by $C$. globularis diffusely occurred. On the other hand, the distribution of charophytes was also significantly affected by substratum type and topology (slope inclination of littorals and lake edges) (Lambert, 2007). In presence of steep shores (as in the northern sector of the basin) and coarse sediments, $C$. globularis and other few characean species (with very low frequency) were found almost exclusively; on the contrary, a major fraction of charophyte diversity was concentrated in the shallower southern portion of the Garda lake, mainly in the Veneto region portion of the basin that is characterised by the predominance of fine-grained and silt sediments and very gentle slopes.

\section{CONCLUSIONS}

In conclusion, regular data on the charophyte diversity in the Garda lake focusing on main ecological gradients (depth and space) of most abundant and frequent species are now available for the first time. Besides, the present records highlight the broad range of local distribution and the potential wide areas colonised by charophytes along the lake littorals. Therefore, the Garda lake can be recognised as a centre of charophyte diversity with valuable repercussions on national and European charophyte conservation strategies.

\section{ACKNOWLEDGMENTS}

This study was co-organised by the EULAKES Project (EU Central Europe Programme 2010-2013). This study would have not been possible without the technical assistance of P. Testa, L. Fravezzi, F. Fedrizzi, G. Patti, and M. Mazzurana. The authors would also like to thank the association Volontari del Garda, the Italian National Fire Brigades of Trento and Bardolino and the Diving Unit of Vicenza for coordination, assistance and all the field support.

\section{REFERENCES}

Auderset Joye D, Castella E, Lachavanne JB, 2002. Occurrence of Characeae in Switzerland over the last two centuries (18002000). Aquat. Bot. 72:369-385.

Azzella MM, Iberite M, Fascetti S, Rosati L, (2013). (in press). Loss detection of aquatic habitats in Italian volcanic lakes using historical data. Plant Biosyst.

Bazzichelli G, Abdelahad N, 2009. [Flora analitica delle Caroficee]. [Book in Italian]. Università La Sapienza ed., Roma: 75 pp.

Bianchini F, Bertoldi G, Tessari M, 1974. [Floristica e fitosociologia delle macrofite], p. 225-240. In: [Indagini sul lago di Garda]. [Book in Italian]. CNR Publ.

Blaženčić J, Stevanović B, Blaženčić Z, Stevanović V, 2006. Red data list of chariphytes in the Balkans. Biodivers. Conserv. 15:3445-3457.

Blindow H, 1992. Decline of charophytes during eutrophication: comparison with angiosperms. Freshwater Biol. 28:9-14.

Bolpagni R, 2013. Macrophyte richness and aquatic vegetation complexity of the Lake Idro (Northern Italy). Ann. Bot. (Roma) 3:77-85.

Bolpagni R, Pierobon E, Longhi D, Nizzoli D, Bartoli M, Tomaselli M, Viaroli P, 2007. Diurnal exchanges of $\mathrm{CO}_{2}$ and $\mathrm{CH}_{4}$ across the water-atmosphere interface in a water chestnut meadow (Trapa natans L.). Aquat. Bot. 87:43-48.

Borsani G, Contorbia S, 2000. [Indagine conoscitiva delle macrofite sommerse nel lago di Garda e piano per la loro gestione]. [Book in Italian]. Autorità di bacino del fiume Po ed., Parma: $127 \mathrm{pp}$.

Bresciani M, Bolpagni R, Braga F, Oggioni A, Giardino C, 2012. Retrospective assessment of macrophytic communities in southern lake Garda (Italy) from in situ and MIVIS (Multispectral Infrared and Visible Imaging Spectrometer) data. J. Limnol. 71:180-190.

Caraco NF, Cole JJ, 2002. Contrasting impacts of a native and alien macrophyte on dissolved oxygen in a large river. Ecol. Appl. 12:1496-1509.

European Commission, 1992. Commission Decision of 21 May 1992 on the conservation of natural habitats and of wild fauna and flora, 92/43/EEC. In: Official Journal, L 206, 22/07/1992, pp. 7-50.

European Commission, 2000. Commission Decision of 23 October 2000 establishing a framework for community action in the field of water policy, 2000/60/EC. In: Official Journal, L $327,22 / 12 / 2000$, pp. 1-72.

Kufel L, Kufel I, 2002. Chara beds acting as nutrient sinks in shallow lakes: a review. Aquat. Bot. 72:249-260.

Lambert SJ, 2007. The environmental range and tolerance limits of british stoneworts (Charophytes). PhD Thesis. University of East Anglia ed., Norwich.

Ludovisi A, Pandolfi P, Taticchi MI, 2004. A proposed framework for the identification of habitat utilisation patterns of macrophytes in River Po catchment basin lakes (Italy). Hydrobiologia 523:87-101.

Middelboe AL, Markager S, 1997. Depth limits and minimum light requirements of freshwater macrophytes. Freshwater Biol. 37:553-568.

Nygaard G, Sand-Jesen K, 1981. Light cliamate and metabolism of Nitella flexilis (L. Ag. In bottom waters of oligotrophic lake Grane Lagsø, Denmark. Int. Rev. Ges. Hydrobio. 66:685-699. 
Oggioni A, Buzzi F, Bolpagni R, 2011. [Indici macrofitici per la valutazione della qualità ecologica dei laghi: MacroIMMI e MTIspecies], p. 52-80. In: A. Marchetto, A. Lugliè, B.M. Padedda, M.A. Mariani, N. Sechi, N. Salmaso, G. Morabito, F. Buzzi, M. Simona, L. Garibaldi, A. Oggioni, R. Bolpagni, B. Rossaro, A. Boggero, V. Lencioni, L. Marziali, P. Volta, M. Ciampittiello (eds.), [Indici per la valutazione della qualità ecologica dei laghi], Report CNR - ISE 03-11. [Book in Italian]. CNR Publ.

Pall K, Moser V, 2009. Austrian index macrophytes (AIMmodule1) for lakes: a water framework directive compliant assessment system for lakes using aquatic macrophytes. Hydrobiologia 633:83-104.

Petr T, 2000. Interactions between fish and aquatic macrophytes in inland waters. FAO Fisheries Technical Paper, No. 396. FAO Publ., Roma: 185 pp.

Pierobon E, Bolpagni R, Bartoli M, Viaroli P, 2010. Net primary production and seasonal $\mathrm{CO}_{2}$ and $\mathrm{CH}_{4}$ fluxes in a Trapa natans L. meadow. J. Limnol. 69:225-234.

Salmaso N, Boscaini A, Cappelletti C, Ciutti F, 2009. [Le condizioni di salute del lago di Garda: aggiornamento dello stato delle conoscenze sui carichi di nutrienti algali e sulle componenti biologiche della zona pelagica e litorale], p. 49-88. In: Proc. Conf. [Problematiche ambientali del Lago di Garda. Approfondimenti e proposte di risanamento], Torri del Benaco, 13 March 2009. [Proceedings in Italian].

Salmaso N, Mosello R, 2010. Limnological research in the deep southern subalpine lakes: synthesis, directions and perspectives. Adv. Oceanogr. Limnol. 1:29-66.

Sauro, U. 2001. [La macchina idraulica]. In: U. Sauro, C. Simoni, E. Turri and G.M. Varanini (eds.), [Il lago di Garda]. [Book in Italian]. Cierre ed., Caselle di Sommacampagna: $496 \mathrm{pp}$.

Scheffer M, Hosper SH, Meijer ML, Moss B, Jeppesen E, 1993.
Alternative equilibria in shallow lakes. Trends Ecol. Evol. $8: 275-279$.

Scheffer M, Jeppesen E, 2007. Regime shifts in shallow lakes. Ecosystems 10:1-3.

Schwarz A-M, de Winton M, Hawes I, 2002. Species-specific depth zonation in New Zealand charophytes as a function of light availability. Aquat. Bot. 72:209-217.

Siemińska J, Bąk M, Dziedzic J, Gąbka M, Greforowicz P, Mrozińska T, Pełechaty M, Owsiany PM, Pliński M, Witkowski A, 2006. Red list of algae in Poland, p. 37-52. In: Z. Mirek, K. Zarzycki, W. Wojewoda and S. Szeląg (eds.), Red list of plant and fungi in Poland. W. Szafer Institute of Botany, Polish Academy of Science ed.

Simons J, Nat E, 1996. Past and present distribution of stoneworts (Characeae) in The Netherlands. Hydrobiologia 340:127-135.

Smart AC, Harper DM, Malaisse F, Schmitz S, Coley S, Gouder de Beauregard AC, 2002. Feeding of the exotic Louisiana red swamp crayfish, Procambarus clarkii (Crustacea, Decapoda), in an African tropical lake: lake Naivasha, Kenya. Hydrobiologia 488:129-142.

Soana E, Racchetti E, Laini A, Bartoli M, Viaroli P, 2011. Soil budget, net export and potential sinks of nitrogen in the lower Oglio river watershed (northern Italy). Clean-Soil Air Water 39:956-965.

Torn K, Martin G, Kukk H, Trei T, 2004. Distribution of charophyte species in Estonian coastal water (NE Baltic Sea). Sci. Mar. 68:129-136.

Welch HE, Kalff J, 1974. Benthic photosynthesis and respiration in Char lake. J. Fish. Res. Board Can. 31:609-620.

Wiegleb G, 1983. [Einige Bemerkungen zur Wasserpflanzenflora des Gardasee-Gebietes]. [Article in German]. Ber. Bayer. Bot. Ges. 54:123-125. 